Chapter 1

\title{
Bloom-Forming Cyanobacteria and Other Phytoplankton in Northern New Jersey Freshwater Bodies
}

\author{
Tin-Chun Chu and Matthew J. Rienzo \\ Additional information is available at the end of the chapter \\ http://dx.doi.org/10.5772/54481
}

\section{Introduction}

\subsection{Phytoplankton}

Phytoplankton not only plays a vast role in the aquatic food chain, but some groups are essential in the production of atmospheric oxygen [1]. Phytoplankton include cyanobacteria, algae and many other groups. Some of the most common types of phytoplankton in North American freshwater bodies include species of Bacillariophyceae (diatoms) as well as thousands of species of cyanobacteria.

Diatoms are a type of phytoplankton that possess several unique contours due to a cell wall composed of silicon dioxide $\left(\mathrm{SiO}_{2}\right)$ [2, 3]. The diatoms, or Bacillariophyta, have distinct structures and thus are easily identifiable in a water sample. Diatoms can be found in a large range of $\mathrm{pH}$ and dissolved oxygen values as well as in ecosystems with a wide concentration of solutes, nutrients, contaminants, and across a large range of water temperatures due to their durable cell walls [2].

There are many species of cyanobacteria, commonly found in freshwater lakes and ponds as well as marine environments. Originally called blue-green algae because of their color, cyanobacteria is a phylum of bacteria that uses photosynthesis to obtain energy. Cyanobacteria are prokaryotes and possess the pigment chlorophyll $a$, which is necessary for oxygenic photosynthesis and can be exploited during molecular analysis to detect the presence of cyanobacteria in a sample [4]. Cyanobacteria aided in the transformation of the Earth's atmosphere by producing atmospheric oxygen [1]. Freshwater cyanobacteria can be found as unicellular, filamentous, or colonial cells within the environment. Some of the common 
cyanobacteria found in freshwater sources in North America include Synechococcus, Anabaena, Oscillatoria, Nostoc, and Anacystis [2].

\subsection{Algal blooms}

Although the necessity for cyanobacteria and other phytoplankton in the environment is apparent, overgrowth in urbanized areas due to eutrophication results in formation of algal blooms, causing deleterious effects to both aquatic life as well as anything that may come in contact with the water. Some of the common algal bloom-forming cyanobacteria include those with filamentous and colonial cells [5].

Eutrophic freshwater ecosystems may contain a high average algal biomass include phytoplanktons such as cyanobacteria, chlorococcales or dinoflagellates [1, 6]. Eutrophication is the water body's response to added nutrients like phosphate and nitrates. In urbanized areas, the human factor of nutrient introduction to these ecosystems, otherwise known as cultural eutrophication, has recently been considered as one of the most important factors driving the increase in algal bloom frequency as well as intensity [7]. Fertilizer runoff, car washing, and pet wastes being discarded into storm drains are three major modern events causing changes that disturb existing equilibrium between phytoplankton and other aquatic life, accelerating eutrophication [1]. The algal mat that forms at the water's surface can easily prevent sun from penetrating the lower portions of the water. In figure 1 below, an extensive algal bloom is seen in Branch Brook State Park Lake in Newark, NJ.

\subsection{Cyanotoxin}

Algal bloom production can be harmful due to decreased sunlight penetration, decreased dissolved oxygen, and also possible toxin release by certain species of cyanobacteria [8]. Many species of cyanobacteria can produce toxins, posing a further risk for aquatic life. There are about 50 species of cyanobacteria that have been shown to produce toxins which are harmful to invertebrates. Microcystis, Anabaena, Oscillatoria, Aphanizomenon, and Nodularia are a few genera which contain species known to produce cyanotoxins. There are three main types of cyanotoxins. Neurotoxins affect the nervous system, hepatotoxins affect the liver, and dermatoxins affect the skin (NALMS) [9]. It could pose a serious threat for both human and animal health if they consume the water from the contaminated sites. Microcystins and other cyanotoxins are heat stable, thus cannot be destroyed by boiling. Also, many cyanotoxins are not easily separated from drinking water if they are dissolved in water. Currently, there are several cyanotoxins that are on the US EPA Contaminant Candidate List (CCL2) which are being evaluated for human toxicity (NALMS) [10]. Exposure routes of these cyanotoxins are dependent on the purpose of the contaminated water. If the contaminated water is part of a reservoir, the exposure route may be ingestion due to improperly filtered drinking water. If the contaminated water is used for recreational use, the exposure route may be skin, ingestion, or inhalation. Human exposure may also come from ingestion of animals that were living in the contaminated water. Saxitoxins, known neurotoxins secreted by several cyanobacterial species including Anabaena circinalis, are also known as paralytic shellfish toxins (PSTs). These neurotoxins infect shellfish, which in turn infect 
humans who ingest those shellfish [11]. This neurotoxin, along with the other cyanotoxins produced by cyanobacteria, currently has no antidote [12].

\subsection{Detection and treatment of algal blooms}

The need for treatment of contaminated freshwater across the world is at an all-time high due to the increase in urbanization. In order to prevent harmful algal blooms from forming, it is necessary to understand the balance between cyanobacteria and their viruses, cyanophage. Cyanophage are viruses that infect cyanobacteria in a species specific manner and are just as ubiquitous as cyanobacteria in ecosystems [13]. So, the first step in possibly detecting and preventing algal bloom formation is to identify the common species at each susceptible freshwater body. Microscopy can be used to identify organisms found within environmental samples. Microscopy allows for identification as well as determination of cell density within the sample. Microscopy, unfortunately, is inefficient and time consuming. As a complement to microscopy, polymerase chain reaction (PCR) can be employed. PCR can be used to prime for conserved regions among all phyla of cyanobacteria and other phytoplankton. In an environmental sample, it is important to first perform PCR using universal cyanobacterial primers in order to determine the presence of cyanobacteria. There have been previous studies in which both universal and phyto-specific primers have been determined to be effective in amplifying the 16s rRNA genes in cyanobacteria [14, 15]. After cyanobacterial presence has been confirmed, species specific primers are then used to effectively determine the profile of the freshwater ecosystem being tested. Using the combined microscopic analysis with molecular techniques allows for an effective and efficient method in determining cyanobacterial profiles among freshwater ecosystems. Flow cytometry is another method that could be used as a complement to microscopy and PCR. Flow cytometry can exploit the fact that phytoplankton contain chlorophyll $a$. A flow cytometer uses a laser and can perform cell differentiation and quantification based on physical characteristics of cells [16]. With the use of these three methods, a successful profile can be generated observing common species at particular water bodies.

\subsection{Water chemistry and lake turnover}

$\mathrm{pH}$ is a water chemistry parameter that is influenced as much by the external environment than it is internal environment of the water body. The $\mathrm{pH}$ of water is partially affected by the $\mathrm{CO}_{2}$ system components $\left(\mathrm{CO}_{2}, \mathrm{H}_{2} \mathrm{CO}_{3}\right.$, and $\left.\mathrm{CO}_{3}{ }^{2-}\right)$. Under basic conditions $(\mathrm{pH}>7.0)$, the $\mathrm{CO}_{2}$ concentration is related to photosynthesis [17]. Since most algal cells (cyanobacteria or phytoplankton) take in $\mathrm{CO}_{2}$ during their growth process, the $\mathrm{pH}$ of the water body falls within a favorable range for growth of a particular genus or species. Some species, at conditions in which the $\mathrm{pH}$ is more than 8.6, may be limited in $\mathrm{CO}_{2}$ uptake due to inactive ion transport mechanisms. But, it is also known that photosynthesis can occur at a $\mathrm{pH}$ of 9-10 in some species. Reduction of photosynthesis is noted at $\mathrm{pH}$ above 10 in all species [1].

Dissolved oxygen is another water chemistry parameter that is affected by both internal and external environments. As algal blooms grow, eventually they will exhaust all essential nutrients available in the water body. When this occurs, there is a decrease in biomass pres- 
ence, which eventually leads to decaying of the algal bloom, producing a scum that decreases the underlying water's oxygen. This depletion of dissolved oxygen can lead to several changes that include hypoxia, in which the dissolved oxygen concentration has dropped below $4 \mathrm{mg} / \mathrm{L}$, or anoxia, in which there is no detectable oxygen levels in the water, leading to death among most finfish and shell fish [18].

Seasonal pond or lake turnover could have had a profound effect on the abundance and population shift of phytoplankton when comparing the summer and fall collections. Lake turnover is a natural event that results in the mixing of pond and lake waters, caused by the changing temperatures in surface waters during the shifting of seasons [19, 20]. The density and weight of water change when temperature changes in the freshwater lakes. Water is most dense at $4^{\circ} \mathrm{C}$; it becomes less dense when the temperature drops below $4^{\circ} \mathrm{C}$, thus rising to the top [20]. This is how fish and other aquatic life can survive during the winter at the floor of the water body, with the warmer water surrounding them towards the sediment [19]. This feature, along with the fact that colder water having a higher capacity for dissolved oxygen, can support the fact that phytoplankton numbers are significantly reduced during the colder months. Pond or lake turnover could affect the phytoplankton survival by keeping the colder water at the surface of the water body, where phytoplanktons need to remain for sunlight and photosynthesis. Because colder surface temperatures do not support phytoplankton growth, the phytoplankton cell numbers and algal blooms should be greatly reduced after the fall turnover occurs, and may return after the spring turnover is complete.

\subsection{Algal biomass dynamics in Northern New Jersey freshwater bodies}

The New Jersey Department of Environmental Protection (NJDEP) has developed the NJDEP Ambient Lake Monitoring Network, in which lakes and ponds around the state of New Jersey are tested for water quality. The Network tests at least one station and one outlet of each water body. At these stations, the NJDEP tests for total depth, profile depth, Secchi, water temperature, dissolved oxygen, $\mathrm{pH}$, conductivity, phosphorous, nitrates, chlorophyll $a$, and turbidity, among other water quality factors.

Essex County, New Jersey, is one of the most densely populated counties in the state of New Jersey, consisting of a population of 783,969 in a land area of 127 square miles [21, 22]. Essex County is a heavily urbanized county located in the New York Metropolitan area. Essex County contains 12 major highways, three of the nation's major transportation centers (Newark Liberty International Airport, Port Newark, Penn Station), and 1,673 miles of public roads [21]. These factors, combined with the massive industrial centers producing goods ranging from chemicals to pharmaceuticals, contribute to the urbanization of the area. Despite being heavily urbanized, Essex County has several parks, freshwater rivers, lakes, and ponds which contribute to the continued efforts in beautification and habitat diversity of the region. These bodies of water, being continually subjected to harmful elements from manmade chemicals and excess nutrient pollution, have seen an increase in phytoplankton blooms. Increases in the amounts of nutrients entering lakes and reservoirs in recent decades in urbanized settings as well as associated changes in the water body's biologics have contributed to the increase in focus on the problem of nutrient enrichment due to pollution, 
called eutrophication [1, 22]. Eutrophication and harmful algal blooms are serious global environmental issues.

In the present study, five lakes in Essex County, New Jersey were sampled in the summer and fall of 2011. Sites were tested for $\mathrm{pH}$, dissolved oxygen, and temperature to observe environmental conditions which harbor algal bloom formation. Samples were subsequently tested for the presence of cyanobacteria and phytoplankton using the three methods described above: Microscopic analysis, polymerase chain reaction, and flow cytometry. Microscopic analysis was performed to identify individual species of cyanobacteria and other phytoplankton among each site at each of the five lakes tested. Once cyanobacteria were confirmed and several species identified, polymerase chain reaction was used with universal primers to confirm the presence of cyanobacteria as well as species specific primers to confirm the presence of particular species. Flow cytometry was utilized to compare seasonal profiles as well as to compare the cyanobacterial cell concentrations among the water samples.

\section{Materials and methods}

\subsection{Cyanobacterial cultures}

Synechococcus sp. IU 625 and Synechococcus elongatus PCC 7942 strains were used as controls in this study. Five $\mathrm{ml}$ of cells were inoculated in $95 \mathrm{ml}$ of sterilized Mauro's Modified Medium (3M) [23] in $250 \mathrm{ml}$ Erlenmeyer flasks [24]. The medium was adjusted to a pH of 7.9 using $1 \mathrm{M} \mathrm{NaOH}$ or $\mathrm{HCl}$. The cultures were grown under consistent fluorescent lighting and at a temperature of $27^{\circ} \mathrm{C}$. The cultures were grown on an Innova ${ }^{\mathrm{TM}} 2000$ Platform Shaker (New Brunswick Scientific, Enfield, CT, USA) with continuous pulsating at $100 \mathrm{rpm}$.

\subsection{Environmental samples}

Water samples were collected from several water bodies in Essex County, New Jersey in 2011. Permission was granted from the Essex County Department of Parks, Recreation and Cultural Affairs for sample collections. There were two collection periods in this study: May 2011-August 2011 (Summer Collections) and October 2011-November 2011 (Fall Collections) to observe microorganism profile seasonal differences. Three to five samples were collected at each body of water, varying in location and water movement. The five bodies of water observed in this study were Diamond Mill Pond (Millburn, NJ, USA), South Orange Duck Pond (South Orange, NJ, USA), Clarks Pond (Bloomfield, NJ, USA), Verona Lake (Verona, NJ, USA), and Branch Brook State Park (Newark, NJ, USA). Before collection, each site was tested for $\mathrm{pH}$, dissolved oxygen, and temperature using the ExStickII ${ }^{\circledast} \mathrm{pH} /$ Dissolved Oxygen (DO)/ Temperature meter (ExTech ${ }^{\circledR}$ Instruments corp., Nashua, NH, USA). Samples were collected from each water body in 1 L sterile collection bottles (Nalgene, Rochester, NY, USA). The one liter samples were brought to the lab (Seton Hall University, South Orange, NJ, USA) to be further processed. Each sample was run through a coarse filter with a pore size of $2.7 \mu \mathrm{m}$ (Denville Scientific, 
Metuchen, NJ, USA). Filtrate from the coarse filtered sample was run through a fine filter with a pore size of $0.45 \mu \mathrm{m}$ (Nalgene, Rochester, NY, USA). Both coarse and fine filter from each sample were placed in a Thelco ${ }^{\mathrm{TM}}$ Model 2 incubator for drying at $37^{\circ} \mathrm{C}$ (Precision Scientific, Chennai, India). Aluminum foil was sterilized by UV light using a Purifier Vertical Clean Bench (Labconco, Kansas City, MO, USA). Dried filters were placed on sterilized aluminum foil and placed in $-20^{\circ} \mathrm{C}$ freezer for further studies.

\subsection{Genomic DNA extraction}

Genomic DNA of S. IU 625 and S. elongatus PCC 7942 were extracted using Fermentas ${ }^{\circledR}$ Genomic DNA Purification Kit (Fermentas, Glen Burnie, MD, USA). Ten ml of cyanobacteria cells (OD750 $\mathrm{nm}=\sim 1$ ) were placed in a $15 \mathrm{ml}$ conical tube. The conical tubes were then centrifuged and cells were resuspended in $200 \mu \mathrm{l}$ of TE Buffer. $200 \mu \mathrm{l}$ of cells were then mixed with $400 \mu \mathrm{l}$ lysis solution in an Eppendorf tube (Enfield, CT, USA) and incubated in an Isotemp125D ${ }^{\mathrm{TM}}$ Heat Block (Fisher Scientific, Pittsburgh, PA, USA) at $65^{\circ} \mathrm{C}$ for 5 minutes. $600 \mu \mathrm{l}$ of chloroform were added and emulsified by inversion. The sample was then centrifuged at $10,000 \mathrm{rpm}$ for two minutes in a Denville 260D microcentrifuge (Denville Scientific, South Plainfield, NJ, USA). While centrifuging, the precipitation solution was prepared by mixing $720 \mu \mathrm{l}$ of deionized water with $80 \mu \mathrm{l}$ of $10 \mathrm{X}$ concentrated precipitation solution. After centrifugation, the upper aqueous phase was transferred to a new tube and $800 \mu \mathrm{l}$ of the precipitation solution were added. The tube was mixed by several inversions at room temperature for two minutes and centrifuged at 10,000 rpm for two minutes. The supernatant was removed completely and the DNA pellet was dissolved by adding $100 \mu \mathrm{l}$ of $1.2 \mathrm{M} \mathrm{NaCl}$ solution with gentle vortexing. $300 \mu \mathrm{l}$ of cold ethanol (100\%) was added to enable DNA precipitation and kept in $-20^{\circ} \mathrm{C}$ for 10 minutes. The tube was then centrifuged at $10,000 \mathrm{rpm}$ for three minutes. Ethanol was discarded and the pellet was washed with 70\% cold ethanol. The DNA was then dissolved in sterile deionized water, and the DNA concentration and purity were determined with NanoDrop ND-1000 Spectrophotometer (Thermo Fisher Scientific, Wilmington, DE, USA).

\subsection{Chelex® DNA extraction of environmental samples}

All environmental samples underwent a modified Chelex ${ }^{\circledR}$ DNA extraction as follows. Each filter (for both coarse and fine filters) was hole punched 3-4 times at various spots on the filter to produce three to four disks; disks were placed into $1.5 \mathrm{ml}$ Eppendorf tubes. Five hundred microliters of deionized water were added to each tube and each tube was vortexed. Tubes were let stand for 10-15 minutes. All tubes were centrifuged for three minutes at 10,000 rpm to concentrate the pellet. Clear supernatant was discarded from each tube, and $200 \mu \mathrm{l}$ of InstaGene Matrix (Bio-Rad Laboratories, Hercules, CA, USA) were added. Each tube was vortexed for 10 seconds. The tubes were incubated for two hours in a Polyscience ${ }^{\odot}$ Temperature Controller water bath (Polyscience, Niles, IL, USA) at $56^{\circ} \mathrm{C}$, vortexed for 10 seconds, and placed in an Isotemp125D ${ }^{\mathrm{TM}}$ Heat Block (Fisher Scientific, Pittsburgh, PA, USA) for 8 minutes at $100^{\circ} \mathrm{C}$. The tubes were then centrifuged for 10 minutes at 10,000 rpm, and the supernatant (containing DNA) was transferred to clean Eppendorf tubes. The DNA 
concentration and purity were determined with NanoDrop ND-1000 Spectrophotometer (Thermo Fisher Scientific, Wilmington, DE, USA).

\subsection{Polymerase Chain Reaction (PCR)-based assays}

DNA extracted from the environmental samples, along with the controls (S. IU 625, $S$. elongatus PCC 7942) was amplified using general and specific primers to identify the presence of bacteria, cyanobacteria, phytoplankton, and the dominating species. General primers were used to identify bacteria, cyanobacteria, and phytoplankton by utilizing the bacteria-specific 16s rRNA gene primers 27FB and 785R, PSf and PSr, and CPC1f and $\mathrm{CPC} 1 \mathrm{r}$, respectively. Specific primers were used after phytoplankton and cyanobacteria were detected in the samples. PCR was performed using $6.5 \mu$ l nuclease-free deionized water (Promega, Madison, WI, USA), $2.5 \mu \mathrm{l}$ dimethyl sulfoxide (DMSO), $1 \mu \mathrm{l}$ of primer in the forward orientation, $1 \mu \mathrm{l}$ of primer in the reverse orientation, $1.5 \mu \mathrm{l}$ of DNA sample, and $12.5 \mu \mathrm{l} \mathrm{GoTaq}{ }^{\circledR}$ Hot Start Green Master Mix (Promega). Thermocycling was performed in Veriti 96 Well Thermocycler (Applied Biosystems, Carlsbad, CA, USA). The initial denaturation step was at $95^{\circ} \mathrm{C}$ for 2 minutes, followed by 35 cycles of DNA denaturation at $95^{\circ} \mathrm{C}$ for 45 seconds, primer annealing at $50-55^{\circ} \mathrm{C}$ for 45 seconds, and DNA strand extension at $72^{\circ} \mathrm{C}$ for 45 seconds, and a final extension step at $72^{\circ} \mathrm{C}$ for 5 minutes. The amplified DNA was visualized on a $1 \%$ agarose gel with ethidium bromide incorporated using TAE electrophoresis buffer (Fermentas). The gel was visualized using a $2 \mathrm{UV}$ Transilluminator Gel Docit Imaging System (UVP, Upland, CA, USA).

Primers used in this study were either developed using NCBI BLAST (http:// www.ncbi.nlm.nih.gov/BLAST) or by previous studies in this subject field. The sequences of the selected primers, their target organisms and the size of the amplicons are listed in Table 1.

General primers included Phytoplankton-Specific PSf/PSr which identified the 16s rRNA gene in all phytoplankton [17]. Universal primers Uf/Ur identified the 16s rRNA gene in all bacteria [17]. General primers 27FB and 785R were utilized to identify the 16s rRNA in all bacteria, cyanobacteria, and phytoplankton [21]. CPC1f/CPC1r are also cyanobacteria specific primers which identify the $\beta$-Subunit of the phycocyanin gene conserved among all cyanobacteria [15]. AN3801f/AN3801r are also cyanobacteria specific primers, identifying the DNA polymerase III gene conserved in S. IU625 and S. elongatus PCC 7942. Once cyanobacteria and phytoplankton were identified in a sample, specific primers were obtained and utilized. Primers specific for Anabaena circinalis toxin biosynthesis gene cluster were developed using NCBI BLAST searches: ANAf and ANAr. Primers to locate Microcystis were developed in accordance with Herry et al. Diatom presence was identified using primers developed in accordance with Baldi et al. 528f with 650r identified the small subunit ribosomal DNA gene conserved among all diatom species [23]. 


\begin{tabular}{|c|c|c|c|}
\hline Primer & Target Organism & Sequence & Amplicon (bp) \\
\hline CPC1f & \multirow{2}{*}{ Cyanobacteria } & GGCKGCYTGYYTRCGYGACATGGA & \multirow{2}{*}{389} \\
\hline CPC1r & & AARCGNCCTTGVGWATCDGC & \\
\hline $27 \mathrm{fB}$ & \multirow{2}{*}{$\begin{array}{c}\text { Bacteria/ } \\
\text { Photosynthetic plankton }\end{array}$} & AGAGTTTGATCMTGGCTCAG & \multirow{2}{*}{740} \\
\hline $785 r$ & & ACTACCRGGGTATCTAATCC & \\
\hline ANAf & \multirow{2}{*}{ Anabaena circinalis } & GATCTAGCCTCACCTGTTGACTT & \multirow{2}{*}{457} \\
\hline ANAr & & GGGATCCTTTTTGCTGCGCC & \\
\hline $528 f$ & \multirow{2}{*}{ Diatoms } & GCGGTAATTCCAGCTCCAA & \multirow{2}{*}{200} \\
\hline $650 r$ & & AACACTCTAATTTTTTCACAG & \\
\hline PSf & \multirow{2}{*}{ Phytoplankton } & GGGATTAGATACCCCWGTAGTCCT & \multirow{2}{*}{150} \\
\hline Ur & & ACGGYTACCTTGTTACGACTT & \\
\hline Uf & \multirow{2}{*}{ Phytoplankton } & GAGAGTTTGATCCTGGTCAG & \multirow{2}{*}{700} \\
\hline PSr & & CCCTAATCTATGGGGWCATCAGGA & \\
\hline AN380f & \multirow{2}{*}{$\begin{array}{c}\text { S. IU } 625 \text { \& S. elongatus PCC } \\
7942\end{array}$} & CAAATCACTCAGTTTCTGG & \multirow{2}{*}{180} \\
\hline AN380r & & CAGTAGCAGCTCAGGACTC & \\
\hline
\end{tabular}

Table 1. Seven primer sets used for PCR-based assays.

\subsection{Microscopic analyses}

Microscopic images were acquired using a Carl Zeiss AxioLab.A1 phase contrast microscope coupled with a Carl Zeiss AxioCam MRc camera (Carl Zeiss Microimaging, Jena, Germany). Coarse filters ( $2.7 \mu \mathrm{m}$ pores) were hole punched one time. The fragment was placed into an Eppendorf tube and $100 \mu \mathrm{l}$ of deionized water were added. The tubes were left at room temperature for 10-20 minutes. $16 \mu \mathrm{l}$ of the tube's contents were pipetted onto a microscope slide and viewed at 400X power under the phase filter. Images of diatoms, phytoplankton and cyanobacteria were compared to the atlas "Freshwater Algae of North America: Ecology and Classification" [2]. Species of cyanobacteria, diatoms, and phytoplankton were identified for use in specific PCR analysis and amplification.

\subsection{Flow cytometry}

Flow cytometry was performed on several sites collected from Branch Brook State Park (Newark, NJ) in June 2011 as well as December 2011 by a Guava ${ }^{\circledR}$ EasyCyte $^{\mathrm{TM}}$ Plus Flow Cytometry System (Millipore, Billerica, MA, USA). Fluorescence resulting from the excitation 
with a $488 \mathrm{~nm}$ laser was collected using both green and red filters. A $575 \mathrm{~nm}$ filter was used to locate carothenoid pigments, while a $675 \mathrm{~nm}$ filter was used to locate chlorophyll a pigments, each of which would be indicative of cyanobacterial presence in the water sample. Blanks were created by using Phosphate Buffered Saline (PBS) and deionized water. Tubes were prepared by hole punching both coarse and find filters and placing them in Eppendorf tubes with $100 \mu$ l deionized water, as mentioned above. Cyanobacterial presence was studied in the coarse filter from Branch Brook Park site C from July 2011 (Algal Bloom present), Branch Brook Sites C \& D (Raw, unfiltered samples), and both Branch Brook Sites C \& D Coarse and Fine filters. Flow Cytometry results were analyzed using FlowJo 7.6.5 Flow Cytometry Analysis Software (Tree Star, Inc., Ashland, OR, USA).

\section{Results}

\subsection{Water chemistry}

The $\mathrm{pH}$, dissolved oxygen, and temperature were analyzed at all sites in this study. These parameters aided in the development of a profile for each water body, highlighting which environmental conditions allowed for cyanobacterial and other phytoplankton overgrowth. In Table 1 below, the range of water chemistry levels determined at all sites from summer and fall collection is displayed. The data indicated that the $\mathrm{pH}$ range is broader in the fall than in the summer. Dissolved oxygen levels were similar in two seasons and the temperature differences ranged between 6.7 and $20.9^{\circ} \mathrm{C}$.

\begin{tabular}{cccc}
\hline Water Chemistry & $\mathbf{p H}$ & Dissolved Oxygen $(\mathbf{m g} / \mathbf{L})$ & Temperature $\left({ }^{\circ} \mathbf{C}\right)$ \\
\hline Summer & $7.27-8.30$ & $1-10$ & $23.5-30$ \\
\hline Fall & $6.60-9.25$ & $2-11$ & $9.1-16.8$ \\
\hline
\end{tabular}

Table 2. The range of water chemistry parameters for water samples taken at 20 sites during the summer and fall collections is shown.

\subsection{Polymerase Chain Reaction (PCR)-based assays}

Polymerase chain reaction based assays were performed using DNA extracted from both the coarse and fine filters at each site among all water bodies involved in this study collected in both the summer and fall to identify the presence of bacteria, cyanobacteria, and phytoplankton within each body of water.

PCR-based assays were performed on the coarse and fine filters from each site collected from each water body during the summer and the fall collections. Primer sets used for these PCR-based assays include CPC1f/CPC1r and 27fB/785r for general identification of cyanobacteria and photosynthetic bacteria, respectively. Synechococcus sp. IU 625 and Synechococcus elongatus PCC 7942, both lab strains, were used as positive controls in this 
study. In figures 1-3 below, selected gel electrophoresis results from these PCR-based assays are displayed.

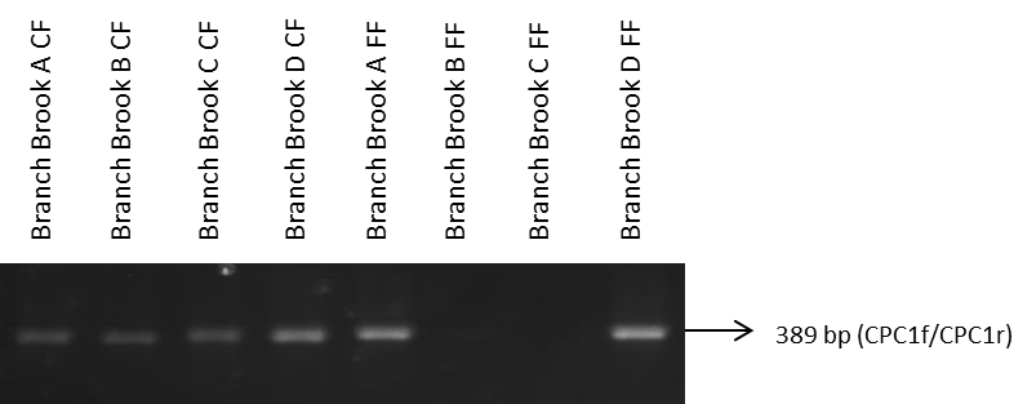

Figure 1. Results from Branch Brook State Park coarse and fine filters are shown using the CPC1f/CPC1r primer set to detect cyanobacteria. It indicates that the presence of cyanobacteria in all 4 sites (A, B, C \& D) of Brank Brook State Park.

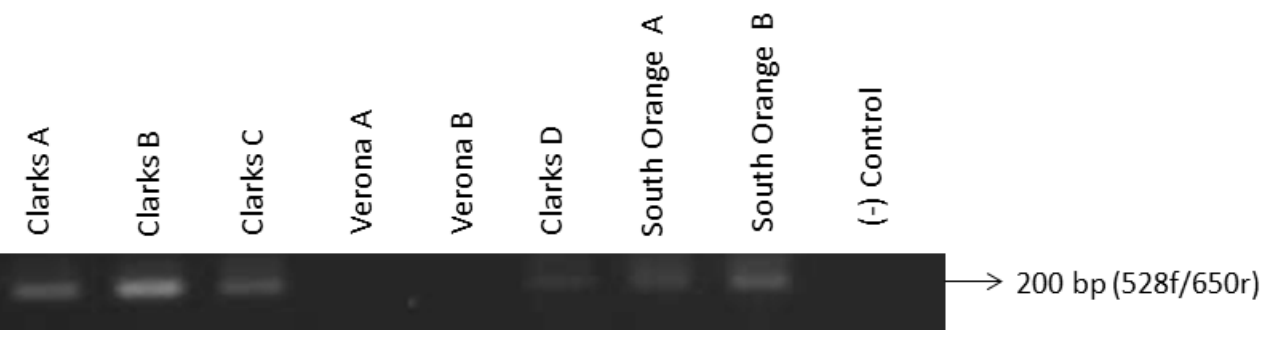

Figure 2. Results from Clarks, Verona and South Orange Duck Pond coarse and fine filters are shown using the 528f/ 650r primer set to detect diatoms. It indicates that the presence of diatoms in all 4 sites (A, B, C \& D) of Clarks Pond and 2 sites of South Orange Duck Pond.

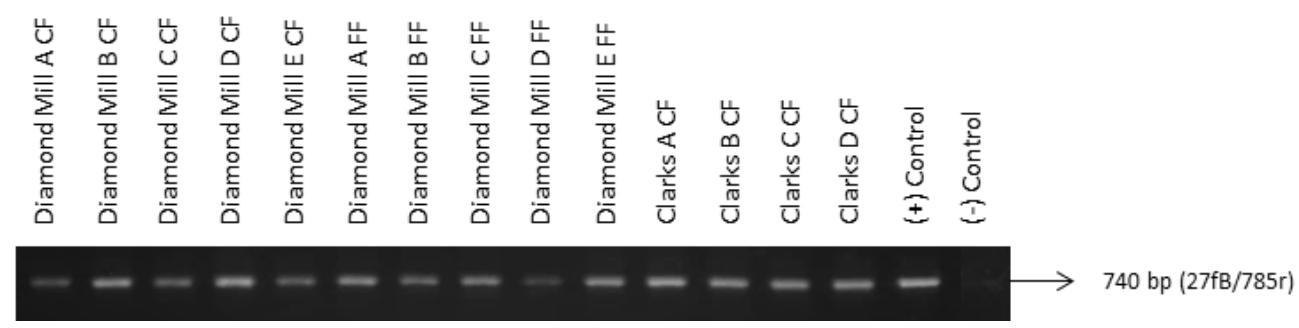

Figure 3. Results from Diamond Mill and Clarks Pond are shown using the $27 \mathrm{fB} / 785 \mathrm{r}$ primer set to detect bacteria and photosynthetic phytoplankton. This is indicative of bacterial and photosynthetic phytoplankton presence among all sites tested. 


\begin{tabular}{cccc}
\hline Water bodies & Sites collected & Summer positive detection & Fall positive detection \\
\hline Brank Brook State Park & A, B, C, D & A, B, C, D $~$ & A, C, D \\
\hline Clarks Pond & A, B, C, D, E & A, B, C, D & ND* \\
\hline Diamond Mill Pond & A, B, C, D & A, C & ND* \\
\hline South Orange Duck Pond & A, B, C, D & A, B & A \\
\hline
\end{tabular}

Table 3. Summary of cyanobacterial detection in the summer and in the fall among 5 water bodies. ND indicates nondetectable. The results showed the fall water samples contain fewer cyanobacteria.

\begin{tabular}{cccc}
\hline Water bodies & Sites collected & Summer positive detection & Fall positive detection \\
\hline Branch Brook State Park & A, B, C, D & A, B, C, D $, C, D$ \\
\hline Clarks Pond & A, B, C, D, E & A, B, C, D & ND* \\
\hline Diamond Mill Pond & A, B, C, D & A & N \\
\hline South Orange Duck Pond & A, B, C, D & A, B \\
\hline Verona Lake & A, B, C & ND* & ND* \\
\hline
\end{tabular}

Table 4. Summary of diatom detection in the summer and in the fall among 5 water bodies. ND indicates nondetectable. The results showed the fall water samples contain fewer diatoms.

In summary, PCR-based assays are able to detect cyanobacteria in 65\% (13 out of 20) of all the sites collected for summer samples and $25 \%$ (5 out of 20) of all sites collected for fall samples. As for diatoms, 55\% (11 out of 20) of the sites indicated presence of diatoms while $20 \%$ (4 out of 20) of the sites showed positive results. Bacteria and photosynthetic plankton are detected in all sites. This study suggested Branch Brook State Park had the most cyanobacteria, diatoms and other phytoplankton among 5 water bodies. The result is consistent to the visual algal bloom observed at these sites. 


\subsection{Microscopic observations}

Each coarse and fine filter were hole-punched, re-suspended in De-Ionized water, and observed under a phase contrast microscope in order to detect, verify, and determine abundant species among each water body at each site. Representative images of cyanobacteria and diatoms were displayed in figures 4-7.

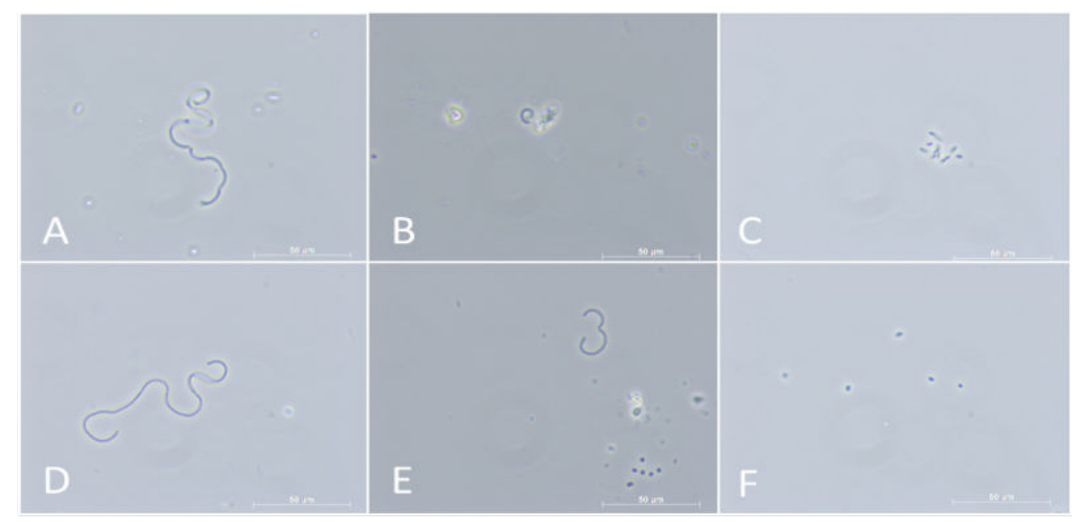

Figure 4. Cyanobacteiral images identified from South Orange Duck Pond. (A) Filamentous cyanobacteria identified from site B. (B) Rod-Shaped cyanobacteria identified from site B. (C) Synechococcus identified from site B. (D) Filamentous cyanobacteria identified from site C. (E) Filamentous cyanobacteria identified from site C. (F) Synechococcus identified from site B. (1000X)

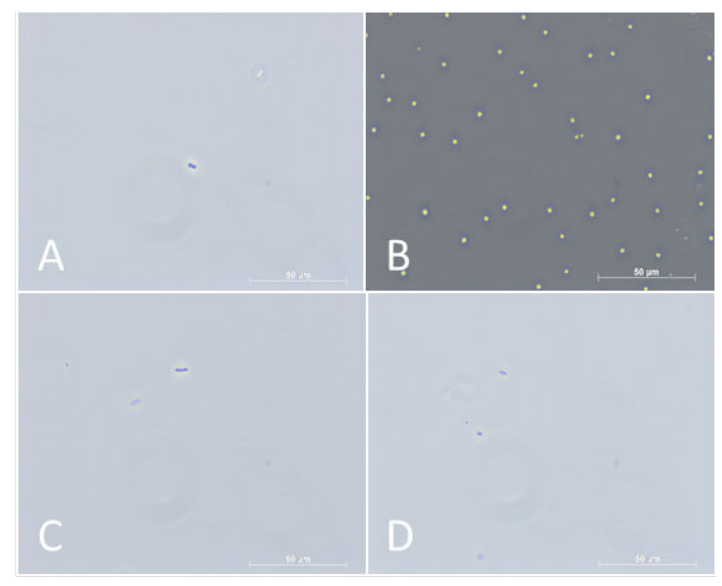

Figure 5. Cyanobacteria identified from Clarks Pond in Bloomfield, NJ. (A) Synechococcus identified from site B. (B) Cyanobacteria identified from site B. (C) Synechococcus identified from site C. (D) Synechococcus identified from site D. $(1000 x)$ 


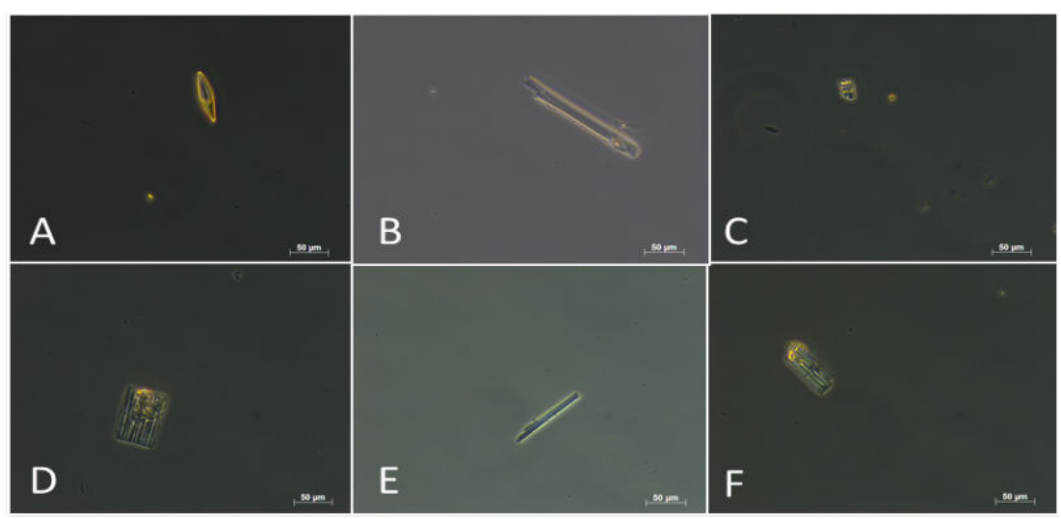

Figure 6. Diatom images identified from Verona Lake in Verona, NJ. (A) Diatom identified from site A. (B) Diatom identified from site B. (C) Diatom identified from site A. (D) Diatom- Fragilaria identified from site A. (E) Diatom identified from site A. (F) Diatom- Fragilaria identified from site B. (400X)

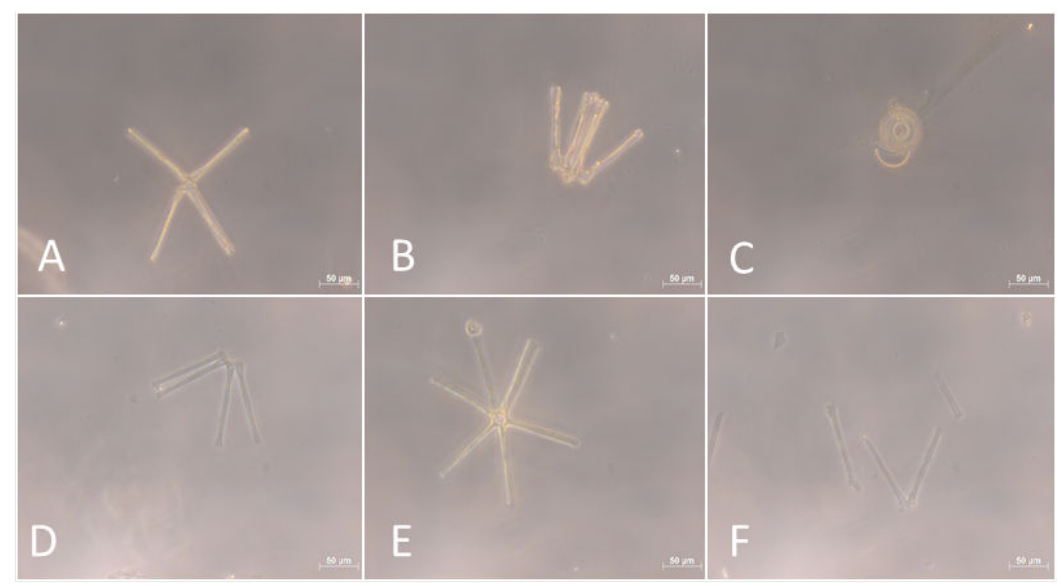

Figure 7. Images of Diatoms at Branch Brook State Park in Newark, NJ. (A) Diatom - Asterionella identified from site A. (B) Diatom - Asterionella identified from site A. (C) Diatom identified from site A. (D) Diatom - Asterionella identified from site B. (E) Diatom - Asterionella identified from site B. (F) Diatom - Asterionella identified from site B. (400X)

A comparison was constructed in order to study the effectiveness of using both PCR and microscopic analysis in identification of the common species of cyanobacteria and other phytoplankton in the water bodies in this study.

Microscopic observation suggested that most microbes among the water sample collected were bacteria, cyanobacteria and diatoms. Cell density were determined and recorded during microscopic analysis from each site of the freshwater ecosystems in this study. Cell den- 
sity was calculated and was subsequently plotted against water chemistry parameters, including $\mathrm{pH}$, dissolved oxygen, and temperature for each site during the summer and fall collections.

\begin{tabular}{|c|c|c|c|c|}
\hline Water Body & Site & Diatoms & Cyanobacteria & Photosynthetic Bacteria \\
\hline \multirow{4}{*}{ Branch Brook Lake } & A & PCR \& MI & PCR \& MI & PCR \& MI \\
\hline & B & $\mathrm{PCR} \& \mathrm{MI}$ & PCR \& MI & $\mathrm{PCR} \& \mathrm{MI}$ \\
\hline & C & $\mathrm{PCR} \& \mathrm{Ml}$ & PCR \& MI & PCR \& MI \\
\hline & $\mathrm{D}$ & $\mathrm{PCR} \& \mathrm{MI}$ & PCR \& MI & PCR \& MI \\
\hline \multirow{4}{*}{ Clarks Pond } & A & PCR & $P C R$ & PCR \\
\hline & B & PCR & $P C R$ & $P C R$ \\
\hline & C & PCR & PCR & PCR \\
\hline & D & PCR & PCR & PCR \\
\hline \multirow{5}{*}{ Diamond Mill Pond } & A & PCR \& MI & PCR \& MI & PCR \& MI \\
\hline & B & $\mathrm{PCR} \& \mathrm{Ml}$ & Ml & PCR \& MI \\
\hline & C & PCR \& MI & PCR \& MI & PCR \& MI \\
\hline & D & $\mathrm{Ml}$ & $\mathrm{Ml}$ & $P C R$ \\
\hline & $\mathrm{E}$ & PCR \& MI & Ml & PCR \& MI \\
\hline \multirow{4}{*}{ South Orange Duck Pond } & A & PCR & PCR \& Ml & PCR \& MI \\
\hline & B & PCR & PCR & PCR \\
\hline & $C$ & MI & MI & PCR \\
\hline & D & $\mathrm{Ml}$ & $\mathrm{Ml}$ & PCR \\
\hline \multirow{3}{*}{ Verona Lake } & A & PCR \& MI & PCR \& MI & PCR \& MI \\
\hline & B & PCR \& MI & MI & PCR \& MI \\
\hline & C & PCR \& MI & $\mathrm{MI}$ & PCR \& MI \\
\hline
\end{tabular}

Table 5. The correlation between microscope findings and PCR findings from summer collections is depicted. 


\begin{tabular}{|c|c|c|c|c|}
\hline Water Body & Site & Diatoms & Cyanobacteria & Photosynthetic Bacteria \\
\hline \multirow{4}{*}{ Branch Brook Lake } & A & PCR \& MI & $\mathrm{PCR} \& \mathrm{Ml}$ & PCR \& MI \\
\hline & B & PCR \& MI & $P C R$ & PCR \& MI \\
\hline & C & $P C R$ & $P C R$ & PCR \& MI \\
\hline & $\mathrm{D}$ & PCR & PCR & PCR \& MI \\
\hline \multirow{4}{*}{ Clarks Pond } & A & $\mathrm{Ml}$ & MI & $\mathrm{PCR} \& \mathrm{Ml}$ \\
\hline & $\mathrm{B}$ & $\mathrm{Ml}$ & $\mathrm{Ml}$ & PCR \& MI \\
\hline & C & $\mathrm{Ml}$ & $\mathrm{Ml}$ & PCR \& MI \\
\hline & D & $\mathrm{Ml}$ & MI & $\mathrm{PCR} \& \mathrm{MI}$ \\
\hline \multirow{5}{*}{ Diamond Mill Pond } & A & $\mathrm{Ml}$ & $\mathrm{Ml}$ & $\mathrm{PCR} \& \mathrm{Ml}$ \\
\hline & B & $\mathrm{Ml}$ & MI & $\mathrm{PCR} \& \mathrm{MI}$ \\
\hline & C & $\mathrm{Ml}$ & MI & $\mathrm{PCR} \& \mathrm{MI}$ \\
\hline & D & $\mathrm{Ml}$ & $\mathrm{Ml}$ & $\mathrm{PCR} \& \mathrm{Ml}$ \\
\hline & $E$ & $\mathrm{Ml}$ & MI & $\mathrm{PCR} \& \mathrm{MI}$ \\
\hline \multirow{4}{*}{ South Orange Duck Pond } & A & MI & $\mathrm{Ml}$ & $\mathrm{PCR} \& \mathrm{MI}$ \\
\hline & B & $\mathrm{Ml}$ & $\mathrm{Ml}$ & $\mathrm{PCR} \& \mathrm{Ml}$ \\
\hline & C & MI & $\mathrm{MI}$ & PCR \& MI \\
\hline & $D$ & $\mathrm{Ml}$ & $\mathrm{Ml}$ & PCR \& MI \\
\hline \multirow{3}{*}{ Verona Lake } & A & $\mathrm{Ml}$ & PCR & PCR \& Ml \\
\hline & B & $\mathrm{Ml}$ & $\mathrm{MI}$ & PCR \& MI \\
\hline & C & MI & MI & PCR \& MI \\
\hline
\end{tabular}

Table 6. The correlation between microscope findings and PCR findings from fall collections is depicted.

\section{Discussion}

Each water chemistry factor ( $\mathrm{pH}, \mathrm{DO}$, temperature) was determined at each site of each water body to gain insight on the environmental conditions that harbor eutrophication and/or algal bloom production. A combination of these physical and chemical properties along with biotic features of the natural water bodies work in a symbiotic manner to determine the sensitivities of these water bodies to eutrophication [18].

For the summer collections, the $\mathrm{pH}$ ranged between 7.27 and 9.20 among all 20 sites. The $\mathrm{pH}$ and cell density agree with the fact that there is a certain $\mathrm{pH}$ range which favors growth. There are several sites in which the $\mathrm{pH}$ was found to be between 7 and 8.5, in which both the highest density of cyanobacteria and diatom were found. As the $\mathrm{pH}$ drops below 7 , however, there were no visible cyanobacteria or diatoms. As the $\mathrm{pH}$ increases to over 8.5 , the cell 
density and the amount of visible cells in the samples visibly decrease. It is understood that the optimal $\mathrm{pH}$ range for cyanobacteria growth is found to be between 7.5 and 10 [26]. During fall collections, the $\mathrm{pH}$ ranged from 6.60 to 9.25 , which again reveals an alkaline environment except for one site (Branch Brook site $\mathrm{C}$ ). The sites with $\mathrm{pH}$ ranging between 7 and 8.5 appear to contain the highest cell count of both diatom and cyanobacteria.
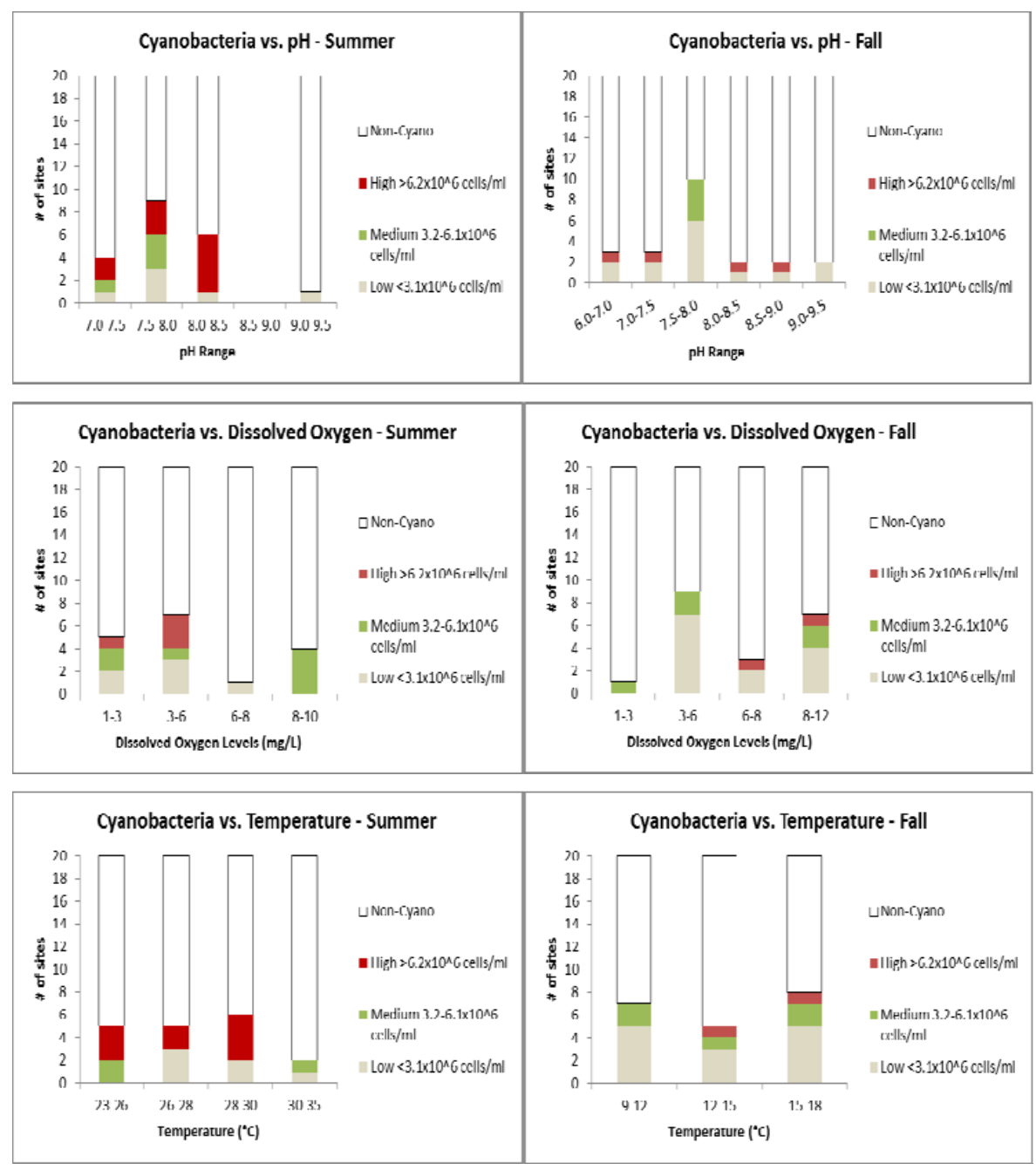

Figure 8. A comparison between cyanobacterial cell density from the summer and the fall collections. Water chemistry parameters include $\mathrm{pH}$, dissolved oxygen, and temperature. the graph shows the number of sites with a high cyanobacteria cell density $\left(>6.2 \times 10^{6} \mathrm{cell} / \mathrm{ml}\right)$ (Red), sites with a medium cyanobacteria cell density $\left(3.2 \times 10^{6}-6.0 \times 10^{6}\right.$ cells $/ \mathrm{ml})$ (Green), and sites with a low cyanobacteria cell density $\left(<3.1 \times 10^{6} \mathrm{cell} / \mathrm{ml}\right)(\mathrm{Grey})$. 

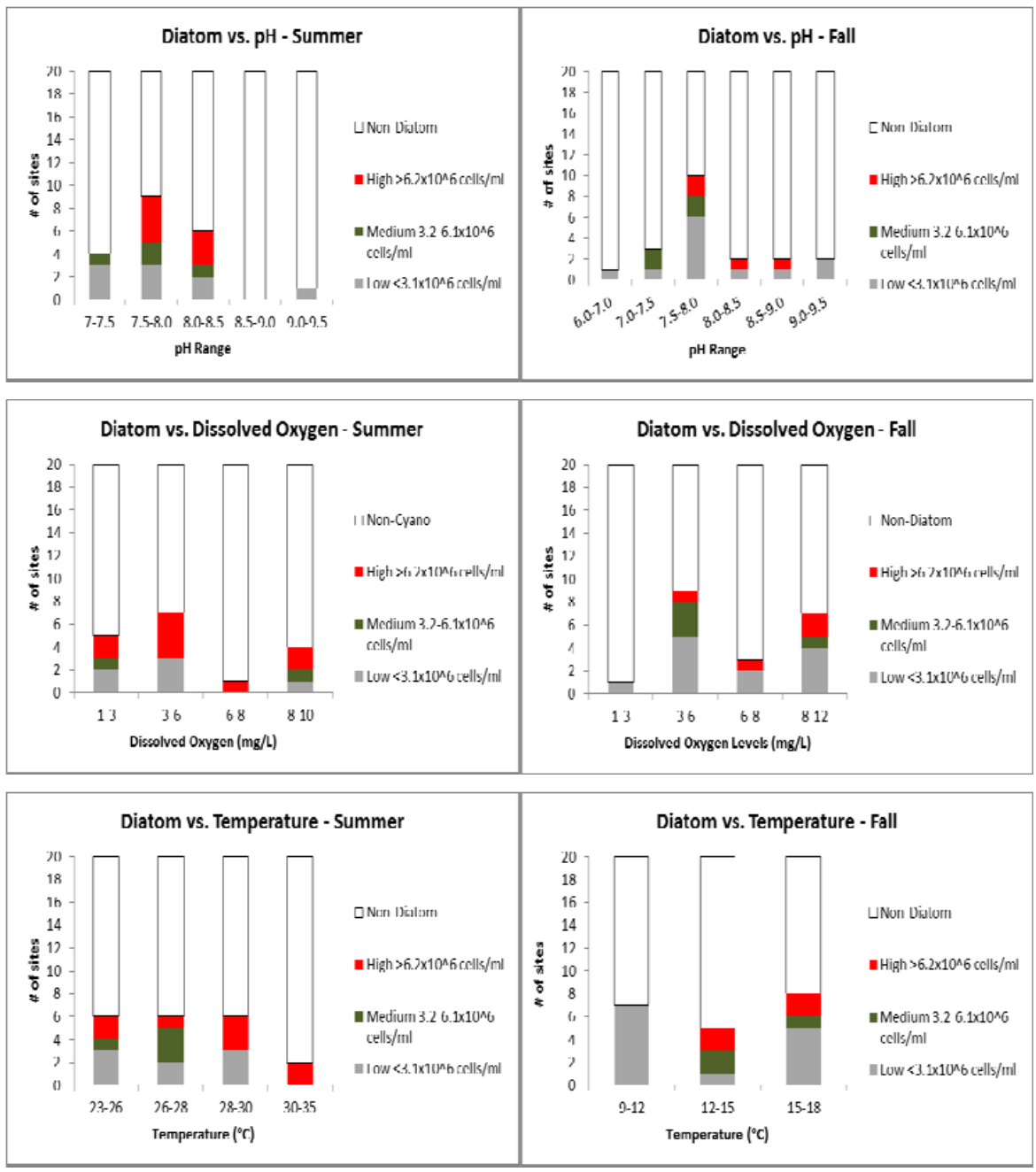

Figure 9. A comparison between diatom cell density from the summer and the fall collections. Water chemistry parameters include $\mathrm{pH}$, dissolved oxygen, and temperature. the graph shows the number of sites with a high diatom cell density $\left(>6.2 \times 10^{6} \mathrm{cells} / \mathrm{ml}\right)$ (Red), sites with a medium diatom cell density $\left(3.2 \times 10^{6}-6.0 \times 10^{6} \mathrm{cells} / \mathrm{ml}\right)(\mathrm{Green})$, and sites with a low diatom cell density $\left(<3.1 \times 10^{6} \mathrm{cells} / \mathrm{ml}\right)($ Grey) .

Among the ponds and lakes tested in the summer collections, dissolved oxygen levels ranged from $1 \mathrm{mg} / \mathrm{L}$ to $10 \mathrm{mg} / \mathrm{L}$, showing a wide range of dissolved oxygen levels. Because it has been previously reported that algal blooms are known to decrease the dissolved oxygen levels [18, 27], it was important to detect a profile of cells found at each dissolved oxygen level. In figures 34 and 35 above, the graph shows both more cyanobacteria as well as diatom cell numbers recorded at sites with a lower dissolved oxygen level $(<5 \mathrm{mg} / \mathrm{L})$. This 
result is important because it displays the correlation between cyanobacteria and other phytoplankton growth and the significant depletion of oxygen in the water column. During the fall collections, the dissolved oxygen levels ranged from $2 \mathrm{mg} / \mathrm{L}$ to $11 \mathrm{mg} / \mathrm{L}$, representing a slight increase in dissolved oxygen which may be a result of decrease in biomass among the water bodies tested, or as a result of lake turnover. Although there are equal numbers among the four sites with countable cell numbers, the cell density are minute when compared to the summer collections. The diatom cell densities appear to be higher among lower dissolved oxygen, although there are still some sites in the higher dissolved oxygen range (8-10 $\mathrm{mg} / \mathrm{L})$ that contain cyanobacteria.

The last factor of water chemistry incorporated into this study was temperature of each site. Temperature has not only been shown to affect the cell size of phytoplankton by controlling enzymatic reactions within the cells, but also to regulate the multiplication rate and standing biomass (phytoplankton population) within the water body. Studies have also shown, though, that it may not be temperature that is limiting the fall and winter growth but the lack of sunlight for photosynthesis $[1,28]$. Water temperature seems to dictate the phytoplankton profile. For example, the cyanobacteria Anabaena has been found to be severely affected by lower temperatures while the diatom Asterionella is not as affected by temperature but a decrease of nutrients in the water body. During the summer collections, the temperatures ranged from 23.5 to $30.2^{\circ} \mathrm{C}$. The amount of cyanobacteria and diatom cells appears to be at a peak between 25 and $30{ }^{\circ} \mathrm{C}$. This is important because it has been previously reported that the optimal growth rate of 'algae' (phytoplankton cells) is between 20 and $25^{\circ} \mathrm{C}$ [1]. As temperature increased from the lowest recorded $\left(23.5^{\circ} \mathrm{C}\right)$, there was a clear increase in both cyanobacteria and diatom cell number, which seemed to decrease after $30^{\circ} \mathrm{C}$. Also, when comparing the phytoplankton distribution between summer collections and fall collections, there is a clear separation in the cell count between the two seasons. This is another finding that corresponds with previous studies that the combination of decreased temperature and decreased light availability for photosynthesis results in decreased phytoplankton growth rate $[1,29]$. The temperature of sites during the fall fell between the ranges of 9.1 and $17.9^{\circ} \mathrm{C}$. As stated above and seen in figures 9 and 10, the cell count of both diatom and cyanobacteria cells are greatly reduced. The higher cell counts of both cyanobacteria and diatoms in the fall collections appeared to fall in the temperature range of between 13 and $17.9^{\circ} \mathrm{C}$. Below $13^{\circ} \mathrm{C}$, there were no readily countable cyanobacteria or diatom cells. This could be due to limited cell growth below the optimal growth rate temperature. Between 13 and $17.9^{\circ} \mathrm{C}$, there were cyanobacteria and diatoms, although at a clearly decreased level when compared to the summer collections and observations. Lake or pond turnover, with a combination of decreasing temperature and increasing dissolved oxygen levels, may have resulted in a decreased amount of phytoplankton cells between summer and fall collections.

Polymerase Chain Reaction (PCR) provided additional verification on the presence of bacteria, cyanobacteria, and algae in the freshwater ecosystems observed. In order to identify phytoplankton, PCR was employed. In order to identify these sequences, house- 
keeping gene sequences were exploited. Housekeeping genes are constantly present and active within living cells, but they do not have to be activated to be identified. The small-subunit ribosomal RNA (16S rRNA) gene segment is a housekeeping gene found within all phototrophs. Because the 16S rRNA gene segment is always present within the genome of cyanobacteria and bacteria cells, this gene segment served as the target for environmental PCR. The universal primers used in this study (27fB/785r, PSf/Ur, Uf/PSr) utilized the 16s rRNA segment to identify cyanobacteria, bacteria, and phytoplankton have been identified in previous studies $[14,15,30]$. The specific primer used in this study to identify the species Anabaena circinalis was developed using NCBI BLAST, while primers for diatoms and Microcystis have been identified in previous studies [31, 32]. In both the summer and fall collections, PCR proved successful in detecting the presence of cyanobacteria, bacteria and phytoplankton by the general "universal" primers identified in previous studies. After detection of these cells within the lakes, a general profile was constructed for each lake.

Branch Brook State Park site C developed a clearly visible algal bloom during the summer collections in July, 2011. During microscopic observation of the coarse filter collected from this site, several species of cyanobacteria were detected. A species of Oscillatoria was detected at site C. Oscillatoria is a type of filamentous cyanobacteria. Oscillatoria, along with other filamentous cyanobacteria, has been previously reported to cause algal blooms [34]. Another cyanobacterium, Radiococcus, was identified at Branch Brook State Park site C. Species of Radiococcus have been detected in small numbers in previous studies [35], but it has not been recorded to cause algal blooms. Because Radiococcus was seen at increased numbers at this site, this cyanobacterium may have been another factor in this algal bloom production and persistence.

Tables 5 and 6 above show the relationship found between microscopy and PCR. Both tables indicate the similarities found between observations made under microscopic observation and PCR. These results prove that although PCR and microscopy may be inefficient on their own, together they are an effective mechanism to develop a phytoplankton profile for freshwater lakes. These findings correlate with previous studies, which have found that it is difficult to distinguish similar cell morphologies by microscopy [36]. Although it is inefficient, microscopy still remains the preeminent means for morphotyping, cell counting, biovolume, viability assays, and life cycle stage observations of cells in a cyanobacterial or phytoplankton bloom [36]. The combination of the microscopic technique and the molecular technique provided for a well detailed and wide analysis of the five ecosystems tested in this study.

Flow cytometry provided a rapid analysis for the overall profile of the sites being tested. Flow cytometry was used to detect the overall photoautotroph presence in the sample by exploiting the auto fluorescence mechanisms of all cells containing the photosynthetic pigment chlorophyll $a$. Flow cytometry was able to show the amount of phycocyanin-containing cells when compared to total cells in the sample. 


\section{Conclusion}

Modified Chelex ${ }^{\circledR}$ DNA extraction is an efficient way to isolate DNA from environmental water samples. When it comes to species identification, PCR-based assays appeared to be more rapid and sensitive than microscopic observation on cyanobacteria and other phytoplankton. Microscopic observation aided in identification of the common genera, while PCR was allowed for identification up to the species level. In addition, flow cytometry was able to provide insight on the phytoplankton profile when used in conjunction with the other two methods. The combination of the three methods can be employed to provide a thorough analysis of the water bodies observed in the study Microscopic observation also allowed for cell density determination, which was important in seasonal comparisons. Water chemistry parameters $(\mathrm{pH}, \mathrm{DO}$, and temperature) were crucial to be incorporated in order to establish the correlation between phytoplankton profile and environmental conditions.

\section{Future studies}

In order to obtain a larger, more complete profile of phytoplankton growth in New Jersey freshwater ecosystems, flow cytometry must be employed at a larger scale. In the current study, it has been established that flow cytometry is successful in the detection of cells containing chlorophyll $a$. In order to develop a rapid yet large profile for many freshwater ecosystems, fluorescent probes must be employed. As used in PCR, the 16s rRNA segments found in all phototrophs can be detected and probed with fluorescence. With these probes, the flow cytometer can successfully identify different species of cyanobacteria and phytoplankton while analyzing mixed microbial populations [25].

As mentioned above, phosphates and nitrates are two of the most important elements resulting from pollution that drive the eutrophication in freshwater ecosystems. Also, as the biomass of cyanobacteria and phytoplankton increase, the amount of chlorophyll $a$ will increase. These factors are important in monitoring and identifying ecosystems that are threatening for algal bloom formation. In order to gain a complete profile for each freshwater ecosystem, these parameters must be incorporated into the future study.

\section{Author details}

Tin-Chun Chu and Matthew J. Rienzo

Department of Biological Sciences, Seton Hall University, South Orange, NJ, USA 


\section{References}

[1] C.S. Reynolds, The Ecology of Freshwater Phytoplankton, Cambridge University Press, 1984.

[2] J.D.Wehr, R.G. Sheath, P. Kociolek, and J.H. Thorp, Freshwater Algae of North America: Ecology and Classification (Aquatic Ecology), Elsevier Science, 2002.

[3] M.J. Leng, and P.A. Barker, "A review of the oxygen isotope composition of lacustrine daitom silica for paleoclimate reconstruction," Earth-Science Reviews, 2005, p. $5-27$.

[4] B.J.F. Biggs, and C. Kilroy, Stream Periphyton Monitoring Manual, The Crown (acting through the Minister for the Environment), 2000.

[5] A. Zingone, and H.O. Enevoldsen, "The diversity of harmful algal blooms: a challenge for science and management," Ocean \& Coastal Management, 2000, p. 725-48.

[6] S.B. Watson, E. McCauley, and J.A. Downing, "Patterns in phytoplankton taxonomic composition across temperate lakes of differing nutrient status," ASLO: Limnology and Oceanography, 1997, p. 487-95.

[7] C.R. Anderson, M.R.P. Sapiano, M.B.K. Prasad, W. Long, P.J. Tango, C.W. Brown, and R. Murtugudde, "Predicting potentially toxigenic Pseudo-nitzschia blooms in the Chesapeake Bay," Journal of Marine Systems, 2010, p. 127-40.

[8] T.C. Chu, S.R. Murray, S.F. Hsu, Q. Vega, and L.H. Lee, "Temperature-induced activation of freshwater Cyanophage AS-1 prophage," Acta Histochemica, May 2011, p. 294-9.

[9] G.A. Codd, L.F. Morrison, and J.S. Metcalf, "Cyanobacterial toxins: risk management for health protection," Toxicology and Applied Pharmacology, 2005, p. 264-72.

[10] EPA, “Water: Contaminant Candidate List (CCL 2),” 2005.

[11] J. Al-Tebrineh, T.K. Mihali, F. Pomati, and B.A. Neilan, "Detection of saxitoxin-producing cyanobacteria and Anabaena circinalis in environmental water blooms by quantitative PCR," Applied and Environmental Microbiology, 2010, p. 7836-42.

[12] CDC, "Facts about Cyanobacteria \& Cyanobacterial Harmful Algal Blooms," 2009.

[13] L.H. Lee, D. Lui, P.J. Platner, S.F. Hsu, T.C. Chu, J.J. Gaynor, Q.C. Vega, and B.K. Lustigman, "Induction of temperate cyanophage AS-1 by heavy metal - copper," BMC Microbiology, 2006, 6:17.

[14] U. Nübel, F. Garcia-Pichel, and G. Muyzer, "PCR primers to amplify $16 S$ rRNA genes from cyanobacteria," Applied and Environmental Microbiology, 1997, p. 3327-32.

[15] J.W. Stiller, and A. McClanahan, "Phyto-specific 16S rDNA PCR primers for recovering algal and plant sequences from mixed samples," Molecular Ecology Notes, 2005, p. 1-3. 
[16] F. Palumbo, G. Ziglio, and A. Van der Beken, Detection methods for algae, protozoa and helminths in fresh and drinking water, John Wiley and Sons, 2002.

[17] F. Moatar, F. Fessant, and A. Poirel, "pH modelling by neural networks. Application of control and validation data series in the Middle Loire river," Ecological Modelling, 1999, p. 141-56.

[18] H.W. Paerl, R.S. Fulton III, P.H. Moisander, and J. Dyble, "Harmful freshwater algal blooms, with an emphasis on cyanobacteria," The Scientific World Journal, 2001, p. 76-113.

[19] MDOC, “Aquaguide: Pond Turnover," Missouri Department of Conservation, 2010, p. 4021_2870.

[20] D.N. Castendyk, and J.G. Webster-Brown, "Sensitivity analyses in pit lake prediction, Martha Mine, New Zealand 1: Relationship between turnover and input water density," Chemical Geology, 2007, p. 42-55.

[21] N.J. Essex County, The County of Essex, New Jersey, 2012.

[22] D.M. Anderson, "Approaches to monitoring, control and management of harmful algal blooms (HABs)," Ocean \& Coastal Management, 2009, p. 342-7.

[23] W.A. Kratz, and J. Myers, "Nutrition and Growth of Several Blue-Green Algae," American Journal of Botany, 1955, p. 282-7.

[24] T.C. Chu, S.R. Murray, J. Todd, W. Perez, J.R. Yarborough, C. Okafor, and L.H. Lee, "Adaption of Synechococcus sp. IU 625 to growth in the presence of mercuric chloride," Acta Histochemica, 2012, p. 6-11.

[25] R.I. Amann, B.J. Binder, R.J. Olson, S.W. Chisholm, R. Devereux, and D.A. Stahl, "Combination of 16s rRNA-targeted oligonucleotide probes with flow cytometry for analyzing mixed microbial populations," Applied and Environmental Microbiology, 1990, p. 1919-25.

[26] N. Giraldez-Ruiz, P. Mateo, I. Bonilla, and F. Fernandez-Piñas, “The relationship between intracellular $\mathrm{pH}$, growth characteristics and calcium in the cyanobacterium Anabaena sp. strain PCC7120 exposed to low pH," New Phytologist, 1997, p. 599-605.

[27] M.L. Saker, M. Vale, D. Kramer, and V.M. Vasconcelos, "Molecular techniques for the early warning of toxic cyanobacteria blooms in freshwater lakes and rivers," Applied Microbial Biotechnology, 2007, p. 441-9.

[28] M.G. Alam, N. Jahan, L. Thalib, B. Wei, and T. Maekawa, “Effects of environmental factors on the seasonally change of phytoplankton populations in a closed fresh-water pond," Environment International, 2001, p. 363-71.

[29] R.W. Sterner, and J.P. Grover, "Algal growth in warm temperature reservoirs; kinetic examination of nitrogen, temperature, light, and other nutrients," Water Research, 1998, p. 3539-48. 
[30] A.L. Barkovskii, and H. Fukui, "A simple method for differential isolation of freely dispersed and partical-associated peat microorganisms," Journal of Microbiological Methods, 2004, p. 93-105.

[31] F. Baldi, C. Facca, D. Marchetto, T.N. Nguyen, and R. Spurio, “Diatom quantification and their distribution with salinity brines in costal sediments of Terra Nova Bay (Antarctica)," Marine Environmental Research, 2011, p. 304-11.

[32] E. Herry S., A. Fathalli, A.J. Rejeb, and N. Bouaïcha, "Seasonal occurrence and toxicity of Microcystis spp. and Oscillatoria tenuis in the Lebna Dam, Tunisia," Water Research, 2008, p. 1263-73.

[33] D.M. Anderson, P.M. Glibert, and J.M. Burkholder, “Harmful Algal Blooms and Eutrophication: Nutrient Sources, Composition, and Consequences," Estuaries, 2002, p. 704-26.

[34] R.J. Montealegre, J. Verreth, K. Steenbergen, J. Moed, and M. Machiels, "A dynamic simulation model for the blooming of Oscillatoria agardhii in a monomictic lake," Ecological Modelling, 1995, p. 17-24.

[35] C.E. Taft, and W.J. Kishler, Algae from Western Lake Erie, The Ohio State University, The Ohio Journal of Science, 1968, p.80-3.

[36] K.A. Kormas, S. Gkelis, E. Vardaka, and M. Moustaka-Gouni, "Morphological and molecular analysis of bloom-forming Cyanobacteria in two eutrophic, shallow Mediterranean lakes," Limnologica-Ecology and Management of Inland Waters, 2011, p. 167-73. 
